\title{
A Qualitative Study on Innovation and Dimensional Aspects of the Omnichannel Retail Business Model
}

\author{
Saiyed Wajid Ali, Jamia Millia Islamia, India \\ Tahir Ahmad Wani, National Institute of Technology, Srinagar, India \\ (iD https://orcid.org/0000-0003-0885-3692
}

Nikita Tyagi, Jamia Millia Islamia, India*

\begin{abstract}
The purpose of the study is to elucidate linkage of the omnichannel retail business model with innovation and technological advancements. The study is exploratory and qualitative in nature, based on primary and secondary data sources collected from varied retail sectors such as fashion, furniture, eyecare, and electronics. The study has used Business Model Canvass (BMC) as a tool for strategic analysis. The study presents findings about business model and strategies in omnichannel context from Indian retailers. The findings of the study posit four main dimensions resultant of digitalization and technological advancements in omnichannel retail, namely omnichannel intensity, organizational structure integration, operations and supply chain management innovation, data analytics and intelligence. Cross-channel integration and data analytics and intelligence have been found to be contributing enormously towards the strategic growth of omnichannel retailers, thus emerging as the prominent managerial implications of the study.
\end{abstract}

\section{KEYWORDS}

Business Model Innovation, Data Analytics and Intelligence, Omnichannel Intensity, Operations and Supply Chain Management Innovation, Organizational Structure Integration, Technological Innovation

\section{INTRODUCTION}

The future of the retail landscape is altering with the advent of technology as the report by McKinsey (2020). The evolving retail sector can be broadly attributed to technology usage in decision making, customer engagement and big data analytics (Bell et al. 2014; Brynjolfsson et al. 2013; Grewal et al. 2017). Technology and automation are not only redrafting the business operational models, value proposition but also changing consumer preferences and purchase behavior. Moreover, consumers are now increasingly using both offline and online retail channels throughout the purchase journey (prepurchase to post-purchase) (Wang et al., 2020), thus making omnichannel retail even more pertinent due to the accelerating changes in modern consumer behavior. Further, the emerging consumer purchase patterns require seamless switching across all retail channels, reinforcing the need for a seamless omnichannel shopping experience. Hence, retailers have also channelized their endeavors towards 
omnichannel strategic management, operations management, organizational structure integration and others (Larke et al., 2018). For instance, IKEA Group (Sweden based multinational furniture retailer) followed the channel integration strategy extensively, enabling customers to shop in ways that suit their needs (Zisko, 2019). Notably, the most remarkable change in retailing is integration of multiple retail channels (Dennis et al., 2016; Grewal et al. 2017; Piotrowicz and Cuthbertson 2014; Rigby 2011) to offer a ubiquitous experience to customers (Homburg et al., 2015; Shi et al. 2020). Consequently, omnichannel retail has emerged as the new norm in retail requiring identification of omnichannel customer engagement and strategic omnichannel retailing (Piotrowicz and Cuthbertson, 2019a).

Furthermore, the recent changes brought about by the Covid-19 pandemic have also altered the retailing landscape across the globe for both customers as well as retailers. According to new research by BigCommerce and Retail Dive (2021), around $46 \%$ of retail executives have diverted their investment towards the omnichannel retail strategy, compared to their plans in the pre-pandemic scenario. The global market for omnichannel retail is projected to reach US $\$ 13.46$ billion by 2026 at a CAGR of 6\% during 2021-2026, against the backdrop of altering consumer preferences and retailing modes (Research and Markets, 2021; 360 Research Reports, 2021). Besides, brick and mortar stores expect their footprints to evolve over the next three years, with nearly $80 \%$ of retailers planning to add both online and offline retail channels to reach out to customers through an omnichannel ecosystem (Colliers, 2021). Conclusively, omnichannel retail intends to offer a seamless purchase journey across channels and consistent channel performance to customers; increased sales, customer retention and competitive advantage to retailers, obtained through synergetic performance across channels (Wang et al., 2020).

Scholars have attempted to comprehend and explore omnichannel retailing on multiple fronts. Studies based on different aspects such as omnichannel conceptual understanding (Rigby, 2011), omnichannel shopping behavior (Lazaris et al., 2014), the role of technology and digitization (Hagberg et al., 2017), organizational strategy, omnichannel business models (Wiener et al., 2018) etc. are outcomes of such endeavors. Furthermore, studies have also attempted to identify the impact of digitalization on the business models of brick-and-mortar retail stores. For instance, Hagberg et al. (2017) highlighted a prime observation towards the role of digitalization in converting customers into omnichannel customers. Consequently, the omnichannel retailing strategy has gained prominent attention among scholars to effectively serve the customers. The strategy has been elucidated as a transition on multiple fronts of omnichannel strategy such as Customer Relationship Management (CRM), operations management, marketing management and others (Hansen \& Sia, 2015; PicotCoupey et al. 2016).

Alongside, omnichannel customer behavior, retail logistics, the impact of technology, transition to omnichannel and others are the broad research themes that have been studied under the ambit of demand, supply and strategic aspect of omnichannel retail (Christoforou \& Melanthiou, 2019; Galipoglu et al., 2018; Jocevski et al. 2019). Moreover, the extant studies have also dwelled upon the omnichannel retailing strategy covering order management, operations management (Zhang et al. 2018) and optimal pricing (Radhi and Zhang, 2018). In addition, omnichannel retailers often face challenges while integrating the retail business activities with the process of creating a seamless customer experience (Zhang et al., 2010). Consequently, leading to discrepancies for retailers in the business model transition process to implement omnichannel retailing strategy (Lazaris \& Vrechopoulos, 2014; Piotrowicz \& Cuthbertson, 2019b).

Therefore, the study of the omnichannel retail business model is critically important to synchronize customer expectations with organizational performance. Although, the extant literature on omnichannel business model has focused on business model transitions pertaining to operations (Davis-Sramek et al., 2020), economic decision-making model for strategic assessment (Hosseini et al., 2018), transition and interplay between offline to online retail and associated synergies (Wiener et al., 2018) and the impact of mobile technology on retail business model transition (Liao \& Yang, 2020). 
However, the role of technological advancements and business innovation in omnichannel retail business model context has not been much worked upon by scholars and studies on this aspect remain rare. Thus, the extant literature lacks a comprehensive understanding of the omnichannel business model given the context of innovation in the domain. Therefore, our study intends to relevantly contribute towards the comprehensive inclusion of innovation in an omnichannel business model. The study intends to answer the following research question: what changes are required in the omnichannel business model elements while implementing Business Model Innovation (BMI).

To acknowledge the research question, the study employs the perspective of business model and attempts to identify what qualifies as BMI activities influencing the performance of omnichannel retailers. The BMI activities identified as dimensions have been grouped and mapped under Value Proposition, Value Creation and Delivery, and Value Appropriation (Osterwalder \& Pigneur, 2010) as part of Value Network in Business Model Canvas (BMC). The research framework is based on the interaction of four identified dimensions (part of BMI activities) with the BMC - Omnichannel Intensity, Organizational Structure Integration, Operations and Supply Chain Management Innovation, Data Analytics and Intelligence.

The remainder of the research paper is framed to present the theoretical background and literature on omnichannel BMI, methodology of the study and findings. The findings draw towards conclusion and implications of the research. The last part of the paper presents theoretical implications and managerial usefulness of the work along with the future scope of the study.

\section{THEORETICAL UNDERPINNING}

\section{Distinctiveness of Omni-channel Retail}

Omni-channel is an evolved and integrated form of multi-channel retailing, characterized by a customer-centric approach (Brynjolfsson et al. 2013; Piotrowicz and Cuthbertson 2014; Piotrowicz \& Cuthbertson, 2019, pp. 58-62; Verhoef et al. 2015). Further, omnichannel retailing is a holistic approach encompassing strategic orientation towards seamless customer experience (Picot-Coupey et al. 2016). It encompasses not only different retail channels i.e., physical, online and social media; rather, also includes mobile channels and varied touchpoints as interaction means with the customers (Baxendale et al., 2015; Kent et al., 2016; Mata \& Quesada 2014). With the backdrop of changes in retailing, physical retail stores are experiencing re-invention and re-innovation in the omnichannel ecosystem (Alexander \& Blazquez, 2020; Mosquera et al. 2018). Furthermore, the omnichannel environment is framed with certain crucial aspects related to channel switching, brand loyalty and decision making (Lazaris, 2014). Notably, channel integration, channel service, product category, integrated interactions etc., influence customer engagement, thus forming pivotal elements of omnichannel customer experience (Lee et al., 2019; Shi et al., 2020).

Moreover, omnichannel customer characteristics tend to influence the task-technology fit for retailers (Haider et al., 2019). As the omnichannel consumer decision- making process is influenced by impulsiveness and requirements to touch, it offers insights into different consumer buying stages (Rodríguez-Torrico et al., 2017). In addition, consumer perception not only affects purchase intention in omnichannel retail (Kazancoglu \& Aydin, 2018) but other factors as well, such as service usage etc. (Shen et.al, 2018).

From the perspective of retailers, omnichannel retailing has evolved as a process and strategy of customer management through varied channels and touch-points to offer a synchronized and seamless shopping experience to customers. The degree of cross channel integration (Beck and Rygl, 2015) and channel service configuration quality (Shen et al., 2018) not only enhance customer loyalty but also influence retailer's growth rate facilitating retailer's strategic decision-making process (Neslin and Shankar 2009). Primarily, these factors assist omnichannel retailers to address the 4 Ps - Product (merchandise), Pricing, Promotion and Place (assortment and delivery) (Zhang et al., 2009). Furthermore, supply chain and operations management holds critical importance for 
omnichannel retailer's performance in order to reduce uncertainty in channel performance (Saghiri et al. 2017). The omnichannel distribution system aims to synchronize supply chain management, operations management, return management, backward and forward integration as well as distribution network (Herhausen et al. 2015; Hübner et al. 2016a). Comprehensively, an omnichannel system can be observed as an interacting ecosystem of three basic components - omnichannel customer journey, type of channel and agents (customer or retailer) (Saghiri et al., 2017).

In addition, technology not only influences the customer's purchase intention and behavior (Juaneda-Ayensa et al., 2016; Taufique et. al, 2017) but also affects retail business models, primarily impacting the logistic model (Hagberg et al. 2016). Therefore, technology and innovation have emerged as key contributors towards integrated customer experience as well as retailer's excelled performance (Mosquera et al. 2018). Technology is altering customer experience and retailer's offering simultaneously, thus offering value sources and growth opportunities (Subramaniam et al., 2019). For instance, in-store technology offers an experiential environment and improves customer engagement (Pantano 2015; Piotrowicz \& Cuthbertson, 2014). Thus, assisting the retailers to devise relevant strategies for customer engagement based on customer satisfaction (Antéblian et al. 2014). Given the intervention of technology in omnichannel retail, the retailers are thus required to re-work on the strategy and business model, in order to be strategically competitive.

However, the development in business model approach, given such rapid technological innovations is quite nascent and requires elaborated understanding and efforts. Technologies such as big data analytics and Information System (IS) offer customer and market-related insights to accelerate the process of customer engagement (Kunz et al., 2017) leading to effective strategic management (Huang and Rust, 2018; Kunz et al., 2019). According to McKinsey (2020), a reboot in omnichannel retailing is required to focus on several elements such as technology, operating model, people and customer value proposition. Hence, technological advancements and retail channel propagation have increased the importance of strategy and business model assessment.

Furthermore, the strategic implementation of omnichannel retail using a business model perspective is quintessential to implement real-time actions (Casadesus-Masanell \& Ricart 2010; Sorescu et al. 2011). Although, omnichannel retailing can serve as a source of competitive advantage to retailer given its effective implementation and customer data harnessing (Herhausen et al. 2015; Ross et al. 2017). However, synergies and tensions between online and offline business models play a crucial role in omnichannel business growth since the decentralized structures are more prone to inefficiencies between such business models (Wiener et al. 2018). Therefore, the strategic implementation of effective omnichannel retail requires transpicuous integration and intertwining of strategy and business model elements. Nonetheless, the extant retail strategies directed towards omnichannel transition have emphasized the importance of supply chain management and performance management (Adivar et al., 2019) lacking a comprehensive integration of strategy and business model elements. Moreover, the business model innovation (BMI) is farmed by transitions in extant business activities affecting value proposition, creation and appropriation (Amit and Zott 2010; Sorescu et al. 2011). Consequently, the present study has implemented the BM perspective that can holistically explain this transition process.

\section{Business Model Innovation}

Business model (BM) depicts an organization's way of value creation and delivery to earn profitably (Baden-Fuller \& Morgan, 2010). Prior studies have highlighted BM as an overarching view about an organization's operational strategies and activities concisely representing it as long-term strategy and a source of competence (Amit and Zott, 2001; Osterwalder and Pigneur, 2010). Thus, representing $\mathrm{BM}$ as an essential and practical foundation to channelize activities, explore and represent plausible growth opportunities (Baden-Fuller \& Morgan, 2010). With the proliferation of e-commerce, organizations have transformed traditional business conduct into innovative means (Chesbrough \& 
Rosenbloom, 2002), given the fact that dynamic operational environment impels organizations to adapt and innovate continuously.

Innovations (radical or incremental in nature) in elemental business activities are considered as business model innovations (Bucherer et al., 2012; Osterwalder \& Pigneur, 2010). Across industries, organizations face challenges such as identification of innovation source, internal coordination issues, the cost to associated benefit tradeoff, conflict and stakeholder management etc., while transiting towards business model innovation (Chesbrough, 2010; Karakaya et al., 2016; Visnjic et al., 2018). Given such exploratory insights, the BM perspective when implemented in an omnichannel retail context can unravel exceedingly useful and practical insights. The literature review presents consensus on BM, defining it as "as an organizational framework for value creation, value delivery and value realization" (Amit and Zott, 2001; Demil and Lecocq, 2010; Foss and Saebi, 2017; Osterwalder \& Pigneur, 2010; Teece, 2010). Therefore, a BM perspective in omnichannel retail will foster the identification of business model innovation sources, given the advent of technology and digitalization in retail.

Researchers have highlighted different themes and innovative approaches for retail business models, categorized as value creation and value appropriation (Sorescu et al. 2011; Zott and Amit, 2010). However, technology has emerged as an important source as well as the driver of BMI (Meuter et al. 2005; Padgett and Mulvey 2007; Sood and Tellis 2010) impacting business model elements (Kang, 2018, p. 154; Kunz et al., 2019; Wiener et al., 2018, p. 23), thus altering retailer's strategy and associated business elements (Magretta 2002; Sorescu et al. 2011; Rusanen, 2018). A BM perspective integrates the back end (operational aspect) of the firm with the front-end performance (customer-oriented) (Adivar et al., 2019, p. 261). Further, the extant literature on BM also highlights that retail channels (supply-side) and value creation for customer experience (demand side) form a quintessential part of BM (Massa et al., 2017; Piotrowicz \& Cuthbertson, 2019b). Alongside, the effective implementation of omnichannel retail offers sources of competitive advantage to retailers (Piotrowicz \& Cuthbertson, 2019; Rusanen, 2018). Thus, a comprehensive understanding of strategy and business model is imperative for the evolution and growth of omnichannel retailers (Kumar et al., 2017). Therefore, the study intends to frame the BM perspective in an omnichannel retail context, in terms of innovation or realignment of existing business elements.

In line with these arguments, it is pertinent to note that retail channels form an important component of the Business Model Canvas (BMC) given by Osterwalder and Pigneur (2010). The BMC by Osterwalder and Pigneur (2010) includes nine intertwined elements - customer value proposition, customer segments, customer relationships, channels, key resources, key activities, partners, costs and revenues. Given the context of omnichannel retail, the retail channel is a pivotal element among the nine building blocks of BM. BMC by Osterwalder and Pigneur (2010) is widely accepted and holds a wide representation of business process innovation, thus the present study has used it as a tool to discern the omnichannel business model. BM Canvass is not a static tool, rather involves a constant change in its elements (Bucherer et al., 2012; Hedman \& Kalling, 2003; Jocevski et al., 2019). Hence, the BMC layout has been used as a tool to explore interconnect between technological advancements and constituent BM elements, to gain insights about advancing omnichannel retail business model.

\section{Research Framework}

The objective of analyzing the interconnect between technological advancements and omnichannel $\mathrm{BM}$ is to derive insights about its effective implementation and management. The objective considers BMI activities within the four omnichannel retailing dimensions, namely Omnichannel Intensity, Organizational Structure Integration, Operations and Supply Chain Management Innovation, Data Analytics and Intelligence (Figure I). The considered dimensions have been excerpted from a review of literature and scholarly work on omnichannel retailing (Bettucci et al. 2015; Cai \& Lo, 2020; Jocevski et al., 2019; Taylor et al., 2019). Notably, the foundational stone of omnichannel retail are seamless customer experience and total channel integration. Thus, Omnichannel Intensity as a 
dimension encompasses both the aspects (seamless customer experience and total channel integration) of omnichannel retail. The identified dimensions have been discussed from the perspective of technological advancements and innovations.

Omnichannel Intensity: Digitalization and consistency across channel performance have immensely inflicted shopping experience (Melero et al., 2016). For instance, technology usage in omnichannel retailing offers avenues for seamless and integrated customer experience (Cook, 2014), especially the in-store technologies frames customer's intention and purchase journey in the omnichannel environment (Juaneda-Ayensa et al., 2016). The customer experience is also derived as an outcome of constant interaction across touch-points offered by the brand (Huré et al., 2017; Melero et al., 2016). Broadly, perceived consistency, channel migration, the integrated performance of place, price and promotion organize 'seamless customer experience' which can be measured through shopping value (Babin et al. 1994; Huré et al., 2017).

In addition, integration and visibility are crucial for omnichannel customers and retailers. Channel integration is another quintessential component to form a seamless customer experience (Cao and Li, 2015; Lewis et al., 2014; Picot-Coupey et al., 2016). It encompasses the integration of all retail channels offered by retailers to customers i.e., physical store, online and social (Herhausen et al. 2015). Moreover, the cross-channel integration is immensely affected by the implementation of technological innovation in an omnichannel environment, requiring appropriate capabilities such as data integration, visibility, information symmetricity etc. (Cao 2014; Zhang et al. 2010). Thus, omnichannel retailers are required to leverage upon technology such as Information Management to ensure channel integration and channelize retailing activities saliently (Rangaswamy and Van Bruggen, 2005). Further, analysis of consumer buying habits, productive logistic and supply chain, integration of business processes and others have been found to be enablers of channel integration framing omnichannel strategy (Piotrowicz and Cuthbertson, 2019a). Studies also highlight that omnichannel customer expect total integration including channels, promotions, pricing, order fulfilment and customer service (Adivar et al., 2019; Saghiri et al., 2017). Conclusively, channel integration serves as an effective means to implement an omnichannel strategy (Cao \& $\mathrm{Li}, 2015)$. Therefore, channel consistency, seamless experience and channel integration have been considered as sub-dimensions of Omnichannel Intensity (Huré et al., 2017).

\section{Organizational Structure Integration}

Zhang et al. (2016) propounded key issues faced while implementing omnichannel retail namely business unit conflict, data integration and performance management. Organizational Structure Integration as a dimension identifies synchronization between organizational attributes and requisite innovation in omnichannel retail (Teece, 1996). Organizational characteristics such as organization's size (Pantano, 2014), diversity (Schoenecker \& Cooper, 1998; Teece, 1996), varied resources (financial or human) (Sampson, 2007; Satta et al. 2016) etc. intervene with the innovation process, thus influencing innovative decision-making process as an outcome (Cao \& Li, 2018). Therefore, technological advancements are required to be integrated with organizational structure and process, in order to implement an omnichannel retail business model.

\section{Operations and Supply Chain Management Innovation}

Omnichannel retail focuses on supply chain visibility, inventory management, logistics management, order fulfilment and return management (Adivar et al., 2019; Ailawadi \& Farris, 2017). Given the altering aspect of retailing, operations and supply chain management in omnichannel retail has undergone the process of innovation and advancement (Akturk et al., 2018; Hübner et al., 2016b; Piotrowicz \& Cuthbertson, 2014). Moreover, the demand and supply visibility also hold a pertinent role in omnichannel retail operations (Lau, 2012). Thus, innovations in operations and supply chain management such as integrated information systems, information visibility, intelligent order processing etc. facilitate successful implementation of the omnichannel retailing strategy. 


\section{Data Analytics and Intelligence}

The integrated data analytics and intelligence form a pivotal foundational stone of omnichannel retail. Majorly, this dimension includes harnessing customer and stakeholder's data to leverage it across the retail channels. Its purview encompasses the facilitation of decision making for omnichannel retailers. The three mentioned dimensions of BMI activities are critically interrelated with data analytics and intelligence for their optimal performance. Thus, data integration and business intelligence (Big Data Analytics) provide a competitive advantage to retailers (Arora \& Sahney, 2017; Kumar et al., 2017; Zhang et al., 2018). Moreover, the digital complexities and technological innovations have enhanced the importance of Information System and Big Data Analytics for omnichannel retail (Lazaris et al., 2015), enhancing customer engagement and optimizing retailer's omnichannel performance (Kunz et al., 2017).

Figure 1. Business Model elements and Dimensions in Omnichannel retail

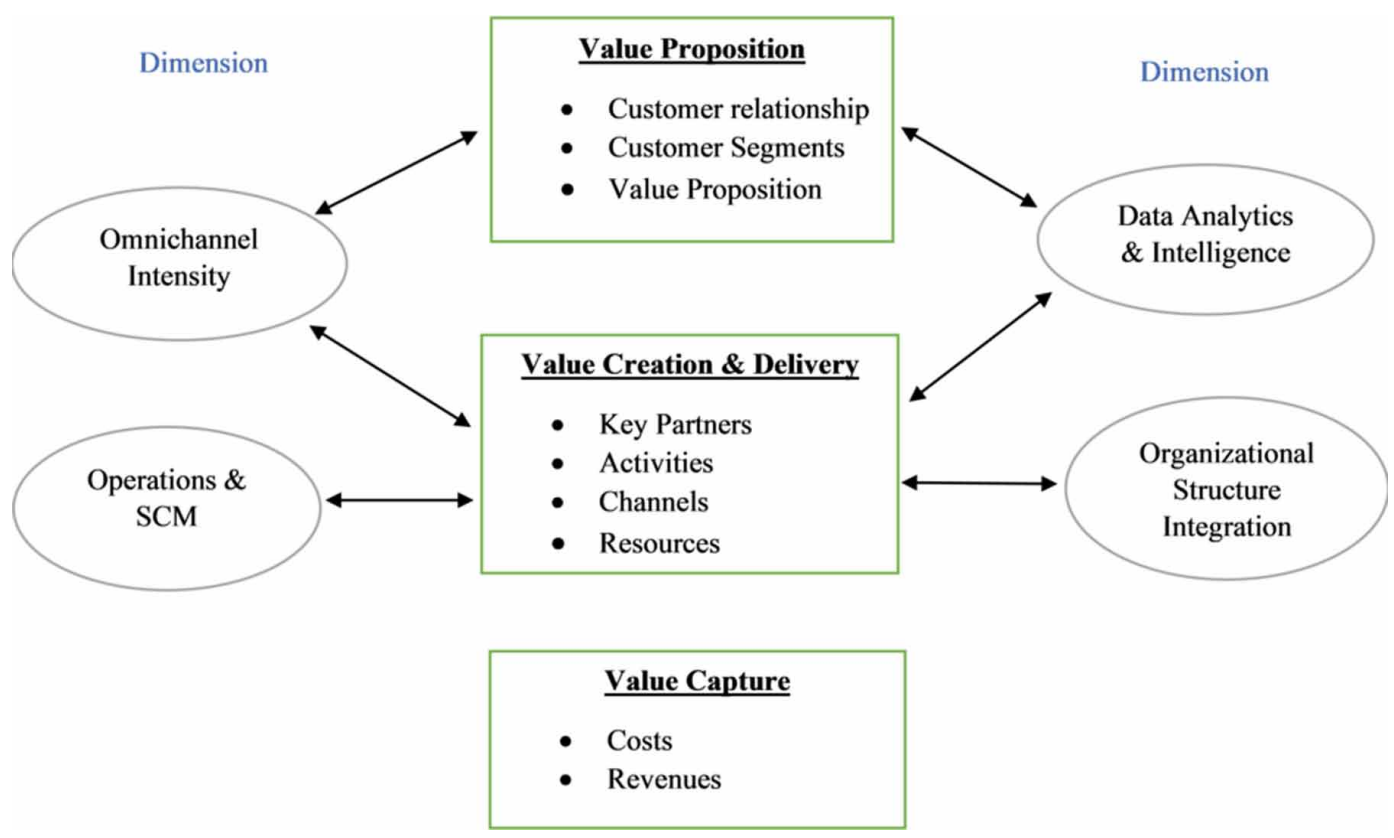

\section{METHODOLOGY}

In qualitative research, case studies are considered appropriate research methodology while gaining insights about a specific issue, concerning an entity (organization or individual) as a unit of analysis (Eisenhardt \& Graebner 2007; Noor, 2008). Therefore, the authors have used an exploratory study approach based on a multiple case basis (Ridder, 2017). The data has been collected from 10 retail firms across four different Indian retail segments through semi-structured interviews. The sample retailers varied across sectors such as fashion, furniture, eyewear and electronics. Both offline and online presence of retailers has been chosen as the inclusion criteria. The sample retailers operate in India and some of them also have global presence.

The semi-structured interviews conducted with store managers were designed to elicit insights regarding the dimensions presented in the research framework. The interviews began at a concrete 
level in terms of sector background of the omnichannel retailing organizations, how the respective organization serve the customer in an omnichannel ecosystem, how these organizations are implementing BMC and how these organizations are coping with innovations affecting BMC (in context of BMI) etc. were the broad aspects further discussed during the interviews.

The interviews were conducted in English at the retailer's site in person with the store manager and typically lasted for an hour which were also audio recorded. The sample omnichannel retailers chosen for the study stand-out in terms of their omnichannel business management, thus the authors have used the collected statements and discussion for devising the general findings regarding BMI in the omnichannel domain.

The authors have used qualitative analyses and by re-listening the recorded interviews, they have looked for information on identified activities categorized under BMI from the review of literature. Initially, each interview was self-analyzed and then subjected to discussion among the authors to avoid single author bias concerning the findings of the study. On completion of all 10 interviews, a common database was prepared to identify commonalities and distinctiveness found in the collected data.

To enrich the findings of the study, data collected from semi-structured interviews has been intertwined with the retailers' public (secondary) data from retailers' websites, mobile applications and annual reports. Moreover, to corroborate findings of the study, information from online stores and mobile applications pertaining to different dimensions and available features such as product visibility, order tracking, order return or cancellation, technological advancement (virtual trial), payment integration, delivery etc. have been examined to explore omnichannel retail management by the retailers.

Also, the analysis was interpretive and involved reference to retailer's secondary data sources along with re-listening the recorded interviews to identify the performance of each respondent retailer on different functionalities. All findings were discussed and clarified with the respondent retailers to validate the results pertaining to functionalities across different dimensions.

However, aspects of consumer behavior integrated with channel integration have not been included in the study, since these are uncontrollable by brands and retailers. Besides, the multiple case study method (Eisenhardt, 1989) provides comprehensive capturing of data pertaining to the research problem. Thus, the sample retailers belonging to a different sector and product category offered varied insights. The retailers have been mapped for pseudo names to maintain anonymity.

To present findings of the study, the authors have used BM canvas presented in Figure 1 and the same has been used during the interviews with the participants.

\section{FINDINGS}

The findings of the study have been mapped out across the four identified dimensions from the literature. Hence, the findings comprehensively present how each interviewed retailer performs across the dimensions as part of BMI. The data analysis of 10 respondent retailers is presented in Table I. The findings of the study have been presented in the table according to different dimensions of BMI.

\section{Omnichannel Intensity}

The study indicates that all companies offered a seamless experience to the customers along with cross channel integration concerning product availability and payment integration. Moreover, physical store presence and web services along with mobile applications are offered by all 10 companies. The aspect of BMI in Omnichannel Intensity is elucidated by click and collect, trails, payment integration etc. Virtual trial as an innovation for Omnichannel Intensity (seamless experience and channel integration) is generally offered by retailers in the fashion sector. During the interviews, the representatives informed that to offer experiential shopping, retailers attempt to provide product visibility on mobile applications and websites on a real-time basis. 
Innovations in the In-store environment such as wi-fi access, virtual trials, click \& collect and promotional activities are endeavored by retailers to increase the seamless experience for customers. Evidently, the underpinning objective of companies is to offer total integration (payment, product, promotion and delivery) to the customers in the omnichannel shopping journey. Similar findings can be observed for click and collect, payment integration as an innovation activity for channel integration. However, the findings infer that complete channel integration can be observed only for a few companies.

Table 1. Functionalities across Dimensions by retailers

\begin{tabular}{|c|c|c|c|c|c|c|c|c|c|}
\hline \multirow[t]{2}{*}{$\begin{array}{c}\text { Tag/ } \\
\text { Identifier }\end{array}$} & \multirow[t]{2}{*}{$\begin{array}{l}\text { Retail } \\
\text { Segment }\end{array}$} & \multirow[t]{2}{*}{ Presence } & \multicolumn{3}{|c|}{ Omnichannel Intensity } & \multirow[b]{2}{*}{$\begin{array}{l}\text { Click \& } \\
\text { Collect }\end{array}$} & \multirow[t]{2}{*}{ OSI } & \multirow[t]{2}{*}{$\begin{array}{c}\text { Operations } \\
\text { \& SCM }\end{array}$} & \multirow[t]{2}{*}{$\begin{array}{c}\text { Data } \\
\text { Analytics }\end{array}$} \\
\hline & & & Physical Store \& web & $\begin{array}{l}\text { Mobile } \\
\text { App }\end{array}$ & $\begin{array}{c}\text { Virtual } \\
\text { Trial }\end{array}$ & & & & \\
\hline 1 & Fashion & India & $\checkmark$ & $\checkmark$ & $x$ & $\checkmark$ & $\checkmark$ & $\checkmark$ & $\checkmark$ \\
\hline 2 & & Global & $\checkmark$ & $\checkmark$ & $x$ & $x$ & $\sqrt{2}$ & - & $\checkmark$ \\
\hline 3 & & India & $\checkmark$ & $\checkmark$ & $\checkmark$ & $x$ & $\checkmark$ & - & $\checkmark$ \\
\hline 4 & & India & $\checkmark$ & $\checkmark$ & $\checkmark$ & $\checkmark$ & $\checkmark$ & $\checkmark$ & $\checkmark$ \\
\hline 5 & & Global & $\checkmark$ & $\checkmark$ & $x$ & $x$ & $\checkmark$ & - & $\checkmark$ \\
\hline 6 & & India & $\checkmark$ & $\checkmark$ & $\checkmark$ & $\checkmark$ & $\checkmark$ & $\checkmark$ & $\checkmark$ \\
\hline 7 & & India & $\checkmark$ & $\checkmark$ & $\checkmark$ & $\checkmark$ & $\checkmark$ & $\checkmark$ & $\checkmark$ \\
\hline 8 & Electronics & India & $\checkmark$ & $\checkmark$ & $x$ & $\checkmark$ & $\sqrt{2}$ & $\checkmark$ & $\checkmark$ \\
\hline 9 & Furniture & India & $\checkmark$ & $\checkmark$ & $x$ & $x$ & $\checkmark$ & - & $\checkmark$ \\
\hline 10 & Eyewear & India & $\checkmark$ & $\checkmark$ & $\checkmark$ & $\checkmark$ & $\checkmark$ & $\checkmark$ & $\checkmark$ \\
\hline
\end{tabular}

Note: $\boldsymbol{V}=$ services offered in dimension $\boldsymbol{X}=$ services not offered in dimension

- = service offered but lacks complete integration in dimension

\section{Organizational Structure Integration (OSI)}

The study includes the representative omnichannel retailers (respondents) with a global presence only in the fashion retail sector (indicated in Table I). The respondents informed that organizational structure and strong brand image enable them to form strong organizational integration. The scope of organizational structure integration is broader than channel integration since the former encompasses the integration of business models (online and offline), policies, procedures and operationalization. The respondent retailers with a global presence have informed to have a more robust form of organization structure integration and associated innovation.

One of the representatives informed that as part of omnichannel strategy, implementation of integrated support activities (Information System, Marketing, Human Resource etc.) by retailers strengthen OSI, in turn facilitating the BMI. Another respondent informed regarding the role of integrated organizational structure, which is to offer a similar shopping experience to customer irrespective of the chosen retail format. Conclusively, all sample retailers are implementing omnichannel institutional mechanisms to ensure Organizational Structure Integration.

\section{Operations and Supply Chain Management Innovation (SCM)}

Despite all sample retailers having physical stores and online presence, not all retailers offer a click and collect facility where the customers can order online (website or mobile application) and pay while order collection or pick-up. The broad insights received from the representatives reveal that 
channel partner management, order fulfilment, vertical integration (for delivery), return management etc. are the main aspects considered while managing operations, supply chain and logistics in the omnichannel domain.

The respondent in the eyewear sector revealed that inventory procurement and management, partner association, order tracking, delivery management are witnessing changes due to innovation in business operations. Moreover, the retailers are able to administer the loopholes in last-mile delivery due to the implementation of technological advancements such as Information Systems, RFID (Radio Frequency Identification), Intelligent order processing etc. at an organizational level.

Additionally, the findings of the study reveal that certain brands which do not offer a click and collect feature as part of channel integration are often confronted with challenges in operations and supply chain innovation.

\section{Data Analytics and Intelligence}

All respondents have equally emphasized upon the role of data analytics and business intelligence in their corresponding sectors. A fashion brand respondent emphasized the importance of data analytics stating it to be the "backbone" of omnichannel retail. Moreover, the analysis of microinteractions across channels assists retailers to enhance their performance, stated another respondent from the furniture sector. Also, big data analytics and business intelligence foster the business development process of omnichannel retailers. Thus, data integration and analytics, Information Systems, Information and Communication tools (ICT) are the essential building blocks of optimum omnichannel performance.

The respondent from the furniture sector shared that the BMI activities not only assist retailers to serve the customers, rather dimensions such as Data Analytics and Intelligence enhance and optimize the back-end business operations as well. The respondents also drew insights from efficient operational models of Flipkart and Amazon, highlighting the contribution of the dimension (Data Intelligence and Analytics) for enhancing value creation and the value delivery process. Thus, the sample retailing brands implementing data analytics and intelligence system at different level (synchronized with operations, channel integration etc.) elucidated the dimension to be interacting with BMI activities.

Conclusively, certain omnichannel retailers i.e., the ones in the fashion sector with a global presence focus more on product availability and robust operations, using the aspects like sources of competitive advantage to offer seamless customer experience. The respondent brand in the electronics sector elucidated the importance of an integrated omnichannel marketing system as part of Omnichannel Intensity and Data Analytics. Similarly, a few respondent retailers in the fashion sector have set up brick and mortar outlets as 'fit studios' not only to ensure physical and online presence, rather implement an integrated marketing strategy through the studios, as a BMI activity enhancing omnichannel performance.

\section{DISCUSSION AND CONCLUSION}

The study has attempted to explore basic elements of omnichannel retail that frame seamless customer experience and strategic aspect of organizational performance. Alongside, the research has used the BM perspective (Baden-Fuller \& Morgan, 2010; Foss \& Saebi, 2017; Osterwalder \& Pigneur, 2010) to explore BMI activities serving as sources of value proposition, value creation \& delivery and value realization due to the proliferation of digitalization in retail (Chesbrough \& Rosenbloom, 2002; Osterwalder et al., 2005; Visnjic et. al 2018).

The study has explored innovations in omnichannel BM through various BMI activities, affecting omnichannel retailer's interaction with customers, considering the sample retailers across different retail sectors.

Figure 1 presents a framework depicting business activities associated with omnichannel retail. The figure depicts four main dimensions namely, Omnichannel Intensity, Organizational Structure 
Integration, Operations and Supply Chain Management Innovation, Data Analytics and Intelligence, primarily crucial for omnichannel retail. Moreover, the authors have identified relevant BM elements for each dimension. Alongside, the research has attempted to identify the required modifications in the evolving omnichannel BM due to technological innovation. The study has identified the modifications using BM as a strategic tool, analyzing each BMI activity under Value Network as Value Proposition, Creation and Delivery. Table II highlights different BMI activities identified as part of the study based on responses obtained from omnichannel retailers.

For Omnichannel Intensity encompassing seamless customer experience and channel integration, the element of value proposition must be redesigned and activities adjoining customer relationship, retail channels and identification of customer segment should be reconsidered. The focus of this dimension according to BM elements should be towards enhancing customer omnichannel experience, offering integrated payments etc. whereas Organizational Structure Integration as a dimension innovates around integrated primary and secondary activities, thus requiring innovation in key activities of BM. For Operations and Supply chain Management, key partnerships and activities pertaining to demand and supply management should be focused on. Finally, to leverage Data Analytics and Intelligence, new knowledge offering activities such as micro-interaction analysis etc. should be

Table 2. Business Model Innovation activities associated with key dimensions of Business Model

\begin{tabular}{|c|c|c|}
\hline Dimension & BM Element & BMI Activities \\
\hline \multirow{5}{*}{$\begin{array}{l}\text { Omnichannel Intensity (Seamless } \\
\text { Experience, Channel Integration) }\end{array}$} & Customer Relationship & $\begin{array}{l}\text { In-store Technology, Frictionless channel } \\
\text { switch, Membership }\end{array}$ \\
\hline & Customer Segment & $\begin{array}{l}\text { Online \& Offline shoppers, Omnichannel } \\
\text { shopping Value }\end{array}$ \\
\hline & Value Proposition & $\begin{array}{l}\text { Seamless experience, Virtual trial, click } \\
\& \text { collect, studios }\end{array}$ \\
\hline & Channels & $\begin{array}{l}\text { Payments Integration, Uniform channel } \\
\text { visibility }\end{array}$ \\
\hline & Key Activities & $\begin{array}{l}\text { Marketing, Operations and SCM } \\
\text { integrated }\end{array}$ \\
\hline Organizational Structure Integration & Key Activities & $\begin{array}{l}\text { Primary \& Secondary activities } \\
\text { integrated }\end{array}$ \\
\hline \multirow{3}{*}{ Operations \& SCM } & Key Partners & $\begin{array}{l}\text { Local associations, order \& return } \\
\text { management }\end{array}$ \\
\hline & Key Activities & $\begin{array}{l}\text { Procurement, Logistics, order processing, } \\
\text { demand \& supply visibility }\end{array}$ \\
\hline & Key Resources & Centralized distribution management \\
\hline \multirow{4}{*}{ Data Analytics \& Intelligence } & Value Proposition & $\begin{array}{l}\text { Personalized and integrated offers \& } \\
\text { promotions across channels, Micro- } \\
\text { interaction analysis }\end{array}$ \\
\hline & Customer Segment & $\begin{array}{l}\text { Identification of customer segments \& } \\
\text { interactions touch-points }\end{array}$ \\
\hline & Key Activities & $\begin{array}{l}\text { Integration across activities for effective } \\
\text { performance }\end{array}$ \\
\hline & Key Resources & $\begin{array}{l}\text { Cross channel integration leveraging } \\
\text { channel performance }\end{array}$ \\
\hline
\end{tabular}


focused to drive the business growth. Here, data pertaining to cross channel switch, customer touchpoints etc. can offer great insights into the realignment of BM elements (see Table II).

Although different omnichannel retailers belonging to different sectors had distinct approach towards the implementation of the omnichannel business model, each had a common objective: serving customer needs, which forms the central aspect of omnichannel retail. Consistent with the findings of previous studies (Hagberg et al. 2016; Mosquera et al. 2018), the research confirms that changes due to technological advancements lead to changes in retailing in order to address the changing customer needs. The authors have reflected upon these changes in form of BMI activities, thus offering a value proposition to customers and performance enhancement to omnichannel retailers. Moreover, the study has emphasized upon the importance of the interaction of BM elements (value proposition, creation and delivery) with BMI activities.

To conclude, it is fascinating to note that despite observing different BM elements and BMI activities (value network) for omnichannel retailers of different sectors, the retailers hold a consensus on seamless interaction with customers across retail channels. For instance, the findings obtained after discussions with omnichannel retailers of the eyecare sector reveals the changing role of physical stores which previously served the purpose of customer engagement (value proposition). This implies that focus on customer needs necessitates the changes in BM design in an omnichannel context. Thus, the study highlights the relevance of business model innovation for omnichannel retailers.

\section{THEORETICAL CONTRIBUTION}

Conclusively, the research highlights that omnichannel retailers can optimize their performance by leveraging total integration of value network with technological advancements. The current study contributes to the BM literature on omnichannel retail by elucidating the theoretical and practical aspects of business models with the assistance of retailers from different retail segments.

Most of the studies on omnichannel strategy and BMI have focused on cross-channel integration as the primary tool for value creation (Piotrowicz \& Cuthbertson, 2019b), whereas our study has identified other dimensions as well besides cross-channel integration, affecting omnichannel BM and strategy. The research has discussed Business Model Canvas in reference to retail innovations using the business innovation process illustrated by Frankenberger et al. (2013). Notably, Sorescu (2011) presented Business Model Innovation through value network, highlighting value creation and value appropriation as means of innovation. However, the authors of the present study posit that value proposition along with value creation, delivery and realization interact with BMI activities to frame omnichannel business models.

Given the wider acceptance of Business Model Canvas by Osterwalder and Pigneur (2010), the study has premised its research on it as a tool. Notably, the authors conform with the findings of previous studies (Bucherer et al., 2012; Jocevski et al., 2019) that BMC is a dynamic tool, presenting the fact that business innovations modify the canvas continuously. The findings unravel various BMI activities under value proposition, value creation and value delivery leveraged by omnichannel retailers to offer an omnichannel experience. Thus, offering a source of competitive advantage to the retailer (Amit and Zott, 2001; Demil \& Lecocq, 2010; Teece, 2010).

Furthermore, the study posits that Omnichannel Intensity is majorly framed by cross channel integration (Huré et al., 2017; Jocevski et al., 2019) since the purview excluded measurement of shopping value and seamless customer experience. Conclusively, the identified dimensions, Omnichannel Intensity, Organizational Structure Integration, Operations and Supply Chain Management Innovation, Data Analytics and Intelligence contribute to the extant literature on the omnichannel elemental framework (Bettucci et al. 2015; Cai \& Lo, 2020; Jocevski et al., 2019; Taylor et al., 2019), propounding new dimensions to the omnichannel business model. Therefore, the dimensions must be further explored and examined to ensure effective omnichannel strategic implementation. 


\section{MANAGERIAL IMPLICATIONS}

The study presents findings and insights from omnichannel retailers of different sectors, thus highlighting two broad managerial implications. Firstly, BM and BMI activities are immensely impacted by technological advancements and innovations. Hence, managers must consider the altering retail landscape in association with innovation while implementing decisions pertaining to consumers and retail organizations. Moreover, the study has illustrated that not all retailers across the product categories fully employ services such as virtual trials, click and collect facility etc. which play pivotal role in forming omnichannel customer experience. Thus, it leaves enormous scope of advancement and growth for such retailers.

Secondly, the role of data analytics and intelligence is enormous and forms the interconnect with other business elements and dimensions. Also, the study holds pertinent implications for managers while designing omnichannel marketing programmes, optimizing business operations and selecting omnichannel business strategies facilitating synchronized performance for an omnichannel retailer. Therefore, the managerial decisions must be based on the cruciality of data, so as to improve customer experience and omnichannel performance.

In addition, the study offers a range of critical activities (BMI dimensions) which must be considered for omnichannel performance evaluation in the context of business model innovation. Thus, omnichannel organizations, retailers and managers must also compare their individualistic performance on current business activities and strategize their relevant course of actions for business model innovation.

\section{LIMITATIONS AND FUTURE SCOPE OF RESEARCH}

The study has attempted to comprehend and explore the altering retail landscape in form of BMI activities. Nevertheless, the study has not presented much insights pertaining to social media as a retail channel. Also, social media has not been discussed much in the context of channel integration and its role in data analytics to enhance omnichannel performance. Moreover, the study has currently included only semi-structured interviews along with retailer's secondary data. However, the study can be enriched by conducting multiple discussion rounds with senior officials of these omnichannel retailers. Thus, the research can be conducted using a mixed study approach (quantitative and qualitative data) to enhance the generalizability of the study and contribute the literature relevantly. Besides, the study has not worked upon the Value Appropriation aspect of Value Network in Business Model Canvas. Thus, future studies can explore interaction of BMI activities with Value Realization (Appropriation) under Value Network. Moreover, omnichannel customer purchase journey and experience have been excluded from the scope of the study. Thus, future studies can also explore the interaction of BMI activities during the customer purchase journey and critically analyze factors influencing omnichannel customer experience, highlighting the importance of each BMC element at different stages of the customer journey. For example, researchers can explore which BMI activity and $\mathrm{BMC}$ elements require changes during customer journey such as information search, payments, delivery etc. Additionally, researchers can observe required changes in BMI and BMC due to changing role of the physical store in omnichannel retail. 


\section{REFERENCES}

Adivar, B., Hüseyinoğlu, I. Z. Y., \& Christopher, M. (2019). A quantitative performance management framework for assessing omnichannel retail supply chains. Journal of Retailing and Consumer Services, 48, 257-269. doi:10.1016/j.jretconser.2019.02.024

Ailawadi, K. L., \& Farris, P. W. (2017). Managing Multi- and Omni-Channel Distribution: Metrics and Research Directions. Journal of Retailing, 93(1), 120-135. doi:10.1016/j.jretai.2016.12.003

Akturk, M. S., Ketzenberg, M., \& Heim, G. R. (2018). Assessing impacts of introducing ship-to-store service on sales and returns in omnichannel retailing: A data analytics study. Journal of Operations Management, 61(1), 15-45. doi:10.1016/j.jom.2018.06.004

Alexander, B., \& Blazquez Cano, M. (2020). Store of the future: Towards a (re)invention and (re)imagination of physical store space in an omnichannel context. Journal of Retailing and Consumer Services, 55, 101913. doi:10.1016/j.jretconser.2019.101913

Amit, R., \& Zott, C. (2001). Value creation in E-business. Strategic Management Journal, 22(6-7), 493-520. doi:10.1002/smj.187

Antéblian, B., Filser, M., \& Roederer, C. (2014). Consumption experience in retail environments: A literature review. Recherche et Applications en Marketing, 28(3), 82-109. doi:10.1177/2051570713505471

Arora, S., \& Sahney, S. (2017). Webrooming behaviour: A conceptual framework. International Journal of Retail \& Distribution Management, 45(7/8), 762-781. doi:10.1108/IJRDM-09-2016-0158

Baden-Fuller, C., \& Morgan, M. S. (2010). Business Models as Models. Long Range Planning, 43(2-3), 156-171. doi:10.1016/j.lrp.2010.02.005

Balchandani, A., Hancock, B., Phillips, S., \& Wachinger, T. (2020, June 8). Rebooting retail: How technology will shape the future of retail. McKinsey \& Company. https://www.mckinsey.com/industries/retail/our-insights/ rebooting-retail-how-technology-will-shape-the-future-of-retail

Baxendale, S., Macdonald, E. K., \& Wilson, H. N. (2015). The Impact of Different Touchpoints on Brand Consideration. Journal of Retailing, 91(2), 235-253. doi:10.1016/j.jretai.2014.12.008

Beck, N., \& Rygl, D. (2015). Categorization of multiple-channel retailing in multi-, cross-, and omni-channel retailing for retailers and retailing. Journal of Retailing and Consumer Services, 27, 170-178. doi:10.1016/j. jretconser.2015.08.001

Bell, D. R., Gallino, S., \& Moreno, A. (2014). How to win in an omnichannel world. MIT Sloan Management Review, 56(1), 45-53.

Berman, B., \& Thelen, S. (2018). Planning and implementing an effective omnichannel marketing program. International Journal of Retail \& Distribution Management, 46(7), 598-614. doi:10.1108/IJRDM-08-2016-0131

Bettucci, M., D’Amato, I., Perego, A., \& Pozzoli, E. (2015). Omnicanalita. Come integrare i processi fisici e digitali per una seamless customer experience. Logistica Management, 72-75.

BigCommerce. (2021, May 10). Omnichannel Retail Is Leading Commerce (+ 4 Pillars). https://www. bigcommerce.com/articles/omnichannel-retail/\#why-is-omnichannel-valuable-for-retailers

Brynjolfsson, E., Yu Jeffrey, H. U., \& Rahman, M. S. (2013). Competing in the age of omnichannel retailing. MIT Sloan Management Review, 54(4), 23-29.

Bucherer, E., Eisert, U., \& Gassmann, O. (2012). Towards Systematic Business Model Innovation: Lessons from Product Innovation Management. Creativity and Innovation Management, 21(2), 183-198. doi:10.1111/j.14678691.2012.00637.x

Cai, Y.-J., \& Lo, C. K. Y. (2020). Omni-channel management in the new retailing era: A systematic review and future research agenda. International Journal of Production Economics, 229, 107729. doi:10.1016/j. ijpe.2020.107729

Cao, L. (2014). Business Model Transformation in Moving to a Cross-Channel Retail Strategy: A Case Study. International Journal of Electronic Commerce, 18(4), 69-96. doi:10.2753/JEC1086-4415180403 
Cao, L. (2018). Implementation of omnichannel strategy in the US retail - Evolutionary approach. In W. Piotrowicz \& W. Cuthbertson (Eds.), Exploring the reality of omnichannel retailing: Theory and practice. Springer.

Cao, L., \& Li, L. (2015). The Impact of Cross-Channel Integration on Retailers' Sales Growth. Journal of Retailing, 91(2), 198-216. doi:10.1016/j.jretai.2014.12.005

Cao, L., \& Li, L. (2018). Determinants of Retailers' Cross-channel Integration: An Innovation Diffusion Perspective on Omni-channel Retailing. Journal of Interactive Marketing, 44, 1-16. doi:10.1016/j.intmar.2018.04.003

Casadesus-Masanell, R., \& Ricart, J. E. (2010). From Strategy to Business Models and onto Tactics. Long Range Planning, 43(2-3), 195-215. doi:10.1016/j.lrp.2010.01.004

Chesbrough, H. (2007). Business Model Innovation: It's Not just about Technology Anymore. Strategy and Leadership, 35(6), 12-17. doi:10.1108/10878570710833714

Chesbrough, H. (2010). Business Model Innovation: Opportunities and Barriers. Long Range Planning, 43(2-3), 354-363. doi:10.1016/j.lrp.2009.07.010

Chesbrough, H., \& Rosenbloom, R. S. (2002). The Role of the Business Model in Capturing Value from Innovation: Evidence from Xerox Corporation's Technology Spin-Off Companies. Industrial and Corporate Change, 11(3), 529-555. doi:10.1093/icc/11.3.529

Christoforou, T., \& Melanthiou, Y. (2019). The Practicable Aspect of the Omni-Channel Retailing Strategy and Its Impact on Customer Loyalty. Palgrave Studies in Cross-Disciplinary Business Research, In Association with EuroMed Academy of Business, 239-260.

Colliers. (2021, March). Retail Moving Forward. https://www.colliers.com/en/research/retail-report-spring-2021

Cook, G. (2014). Customer experience in the omni-channel world and the challenges and opportunities this presents. Journal of Direct, Data and Digital Marketing Practice, 15(4), 262-266. doi:10.1057/dddmp.2014.16

Davis-Sramek, B., Ishfaq, R., Gibson, B. J., \& Defee, C. (2020). Examining retail business model transformation: A longitudinal study of the transition to omnichannel order fulfillment. International Journal of Physical Distribution \& Logistics Management, 50(5), 557-576. doi:10.1108/IJPDLM-02-2019-0055

Demil, B., \& Lecocq, X. (2010). Business Model Evolution: In Search of Dynamic Consistency. Long Range Planning, 43(2-3), 227-246. doi:10.1016/j.lrp.2010.02.004

Dennis, C., Alamanos, E., Papagiannidis, S., \& Bourlakis, M. (2016). Does social exclusion influence multiple channel use? The interconnections with community, happiness, and well-being. Journal of Business Research, 69(3), 1061-1070. doi:10.1016/j.jbusres.2015.08.019

Eisenhardt, K. M. (1989). Building Theories from Case Study Research. Academy of Management Review, 14(4), 532-550. doi:10.2307/258557

Eisenhardt, K. M., \& Graebner, M. E. (2007). Theory Building From Cases: Opportunities And Challenges. Academy of Management Journal, 50(1), 25-32. doi:10.5465/amj.2007.24160888

Ellie, H., Husni, K. \& Harjit, S. (2019). An omnichannel approach to retailing: demystifying and identifying the factors influencing an omnichannel experience. The International Review of Retail, Distribution and Consumer Research, 30, 1-23.

Foss, N. J., \& Saebi, T. (2016). Fifteen Years of Research on Business Model Innovation. Journal of Management, 43(1), 200-227. doi:10.1177/0149206316675927

Frankenberger, K., Weiblen, T., Csik, M., \& Gassmann, O. (2013). The 4I-framework of business model innovation: A structured view on process phases and challenges. International Journal of Product Development, 18(3/4), 249. doi:10.1504/IJPD.2013.055012

Galipoglu, E., Kotzab, H., Teller, C., Yumurtaci Hüseyinoglu, I. Ö., \& Pöppelbuß, J. (2018). Omni-channel retailing research - state of the art and intellectual foundation. International Journal of Physical Distribution \& Logistics Management, 48(4), 365-390. doi:10.1108/IJPDLM-10-2016-0292

Grewal, D., Roggeveen, A. L., \& Nordfält, J. (2017). The Future of Retailing. Journal of Retailing, 93(1), 1-6. doi:10.1016/j.jretai.2016.12.008 
Hagberg, J., Jonsson, A., \& Egels-Zandén, N. (2017). Retail digitalization: Implications for physical stores. Journal of Retailing and Consumer Services, 39, 264-269. doi:10.1016/j.jretconser.2017.08.005

Hagberg, J., Sundstrom, M., \& Egels-Zandén, N. (2016). The digitalization of retailing: An exploratory framework. International Journal of Retail \& Distribution Management, 44(7), 694-712. doi:10.1108/IJRDM-09-2015-0140

Haider, S. W., Zhuang, G., Hashmi, H. B. A., \& Ali, S. (2019). Chronotypes' Task-Technology Fit for Search and Purchase in Omnichannel Context. Mobile Information Systems, 2019, 1-9. doi:10.1155/2019/8968264

Hansen, R., \& Sia, S. K. (2015). Hummel's digital transformation toward omnichannel retailing: Key lessons learned. MIS Quarterly Executive, 14(2), 51-66.

Hedman, J., \& Kalling, T. (2003). The business model concept: Theoretical underpinnings and empirical illustrations. European Journal of Information Systems, 12(1), 49-59. doi:10.1057/palgrave.ejis.3000446

Herhausen, D., Binder, J., Schoegel, M., \& Herrmann, A. (2015). Integrating Bricks with Clicks: Retailer-Level and Channel-Level Outcomes of Online-Offline Channel Integration. Journal of Retailing, 91(2), 309-325. doi:10.1016/j.jretai.2014.12.009

Homburg, C., Jozic, D., \& Kuehnl, C. (2015). Customer experience management: Toward implementing "an evolving marketing concept". Journal of the Academy of Marketing Science, 45(3), 377-401. doi:10.1007/ s11747-015-0460-7

Hosseini, S., Merz, M., Röglinger, M., \& Wenninger, A. (2018). Mindfully going omni-channel: An economic decision model for evaluating omni-channel strategies. Decision Support Systems, 109, 74-88. doi:10.1016/j. dss.2018.01.010

Huang, M. H., \& Rust, R. T. (2018). Artificial Intelligence in Service. Journal of Service Research, 21(2), 155-172. doi:10.1177/1094670517752459

Hübner, A., Wollenburg, J., \& Holzapfel, A. (2016b). Retail logistics in the transition from multi-channel to omni-channel. International Journal of Physical Distribution \& Logistics Management, 46(6/7), 562-583. doi:10.1108/IJPDLM-08-2015-0179

Hübner, A. H., Kuhn, H., \& Wollenburg, J. (2016a). Last mile fulfilment and distribution in omni-channel grocery retailing: A strategic planning framework. International Journal of Retail \& Distribution Management, 44(3), 228-247. doi:10.1108/IJRDM-11-2014-0154

Huré, E., Picot-Coupey, K., \& Ackermann, C.-L. (2017). Understanding omni-channel shopping value: A mixedmethod study. Journal of Retailing and Consumer Services, 39, 314-330. doi:10.1016/j.jretconser.2017.08.011

Jocevski, M., Arvidsson, N., Miragliotta, G., Ghezzi, A., \& Mangiaracina, R. (2019). Transitions towards omni-channel retailing strategies: A business model perspective. International Journal of Retail \& Distribution Management, 47(2), 78-93. doi:10.1108/IJRDM-08-2018-0176

Juaneda-Ayensa, E., Mosquera, A., \& Sierra Murillo, Y. (2016). Omnichannel Customer Behavior: Key Drivers of Technology Acceptance and Use and Their Effects on Purchase Intention. Frontiers in Psychology, 7, 10. doi:10.3389/fpsyg.2016.01117 PMID:27516749

Kang, J.-Y. M. (2018). Showrooming, Webrooming, and User-Generated Content Creation in the Omnichannel Era. Journal of Internet Commerce, 17(2), 145-169. doi:10.1080/15332861.2018.1433907

Karakaya, E., Nuur, C., \& Hidalgo, A. (2016). Business model challenge: Lessons from a local solar company. Renewable Energy, 85, 1026-1035. doi:10.1016/j.renene.2015.07.069

Kazancoglu, I., \& Aydin, H. (2018). An investigation of consumers' purchase intentions towards omnichannel shopping. International Journal of Retail \& Distribution Management, 46(10), 959-976. doi:10.1108/ IJRDM-04-2018-0074

Kent, A., Vianello, M., Blazquez Cano, M., \& Helberger, E. (2016). Omnichannel Fashion Retail and Channel Integration: The Case of Department Stores. In A. Vecchi \& C. Buckley (Eds.), Handbook of Research on Global Fashion Management and Merchandising. IGI Press. doi:10.4018/978-1-5225-0110-7.ch016 
Kim, H.-Y., Lee, J. Y., Mun, J. M., \& Johnson, K. K. P. (2016). Consumer adoption of smart in-store technology: Assessing the predictive value of attitude versus beliefs in the technology acceptance model. International Journal of Fashion Design, Technology and Education, 10(1), 26-36.

Kumar, V., Anand, A., \& Song, H. (2017). Future of Retailer Profitability: An Organizing Framework. Journal of Retailing, 93(1), 96-119. doi:10.1016/j.jretai.2016.11.003

Kunz, W., Aksoy, L., Bart, Y., Heinonen, K., Kabadayi, S., Ordenes, F. V., Sigala, M., Diaz, D., \& Theodoulidis, B. (2017). Customer engagement in a Big Data world. Journal of Services Marketing, 31(2), 161-171. doi:10.1108/ JSM-10-2016-0352

Kunz, W. H., Heinonen, K., \& Lemmink, J. G. A. M. (2019). Future service technologies: Is service research on track with business reality? Journal of Services Marketing, 33(4), 479-487. doi:10.1108/JSM-01-2019-0039

Larke, R., Kilgour, M., \& O'Connor, H. (2018). Build touchpoints and they will come: Transitioning to omnichannel retailing. International Journal of Physical Distribution \& Logistics Management, 48(4), 465-483. doi:10.1108/IJPDLM-09-2016-0276

Lau, K. H. (2012). Demand management in downstream wholesale and retail distribution: A case study. Supply Chain Management, 17(6), 638-654. doi:10.1108/13598541211269247

Lazaris, C. (2014). From Multichannel to Omnichannel Retailing: Review of the Literature and Calls for Research. Academic Press.

Lee, Z. W., Chan, T. K., Chong, A. Y. L., \& Thadani, D. R. (2019). Customer engagement through omnichannel retailing: The effects of channel integration quality. Industrial Marketing Management, 77, 90-101. doi:10.1016/j. indmarman.2018.12.004

Lewis, J., Whysall, P., \& Foster, C. (2014). Drivers and Technology-Related Obstacles in Moving to Multichannel Retailing. International Journal of Electronic Commerce, 18(4), 43-68. doi:10.2753/JEC1086-4415180402

Liao, S.-H., \& Yang, L.-L. (2020). Mobile payment and online to offline retail business models. Journal of Retailing and Consumer Services, 57, 102230. doi:10.1016/j.jretconser.2020.102230

Magretta, J. (2002). Why Business Models Matter. Harvard Business Review, 80(5), 86-92. PMID:12024761

Massa, L., Tucci, C. L., \& Afuah, A. (2017). A Critical Assessment of Business Model Research. The Academy of Management Annals, 11(1), 73-104. doi:10.5465/annals.2014.0072

Mata, F. J., \& Quesada, A. (2014). Web 2.0, Social Networks and E-Commerce as Marketing Tools. Journal of Theoretical and Applied Electronic Commerce Research, 9(1), 11-12. doi:10.4067/S0718-18762014000100006

Melero, I., Sese, F. J., \& Verhoef, P. C. (2016). Recasting the customer experience in today's omnichannel environment. Universia Business Review, 50, 18-37.

Meuter, M. L., Bitner, M. J., Ostrom, A. L., \& Brown, S. W. (2005). Choosing among Alternative Service Delivery Modes: An Investigation of Customer Trial of Self-Service Technologies. Journal of Marketing, 69(2), 61-83. doi:10.1509/jmkg.69.2.61.60759

Mosquera, A., Olarte-Pascual, C., Juaneda Ayensa, E., \& Sierra Murillo, Y. (2018). The role of technology in an omnichannel physical store: Assessing the moderating effect of gender. Spanish Journal of Marketing, 22(1), 63-82.

Neslin, S. A., \& Shankar, V. (2009). Key Issues in Multichannel Customer Management: Current Knowledge and Future Directions. Journal of Interactive Marketing, 23(1), 70-81. doi:10.1016/j.intmar.2008.10.005

Noor, K. B. M. (2008). Case Study: A Strategic Research Methodology. American Journal of Applied Sciences, 5(11), 1602-1604. doi:10.3844/ajassp.2008.1602.1604

Osterwalder, A., \& Pigneur, Y. (2010). Business Model Generation: A Handbookfor Visionaries, Game Changers, and Challengers (T. Clark, Ed.). Wiley.

Osterwalder, A., Pigneur, Y., \& Tucci, C. L. (2005). Clarifying Business Models: Origins, Present, and Future of the Concept. Communications of the Association for Information Systems, 16, 5. doi:10.17705/1CAIS.01601 
Padgett, D., \& Mulvey, M. (2007). Differentiation Via Technology: Strategic Positioning of Services Following the Introduction of Disruptive Technology. Journal of Retailing, 83(4), 375-391. doi:10.1016/j.jretai.2007.03.010

Pantano, E. (2014). Innovation management in retailing: From consumer perspective to corporate strategy. Journal of Retailing and Consumer Services, 21(5), 825-826. doi:10.1016/j.jretconser.2014.02.017

Pantano, E. (2015). Successful Technological Integration for Competitive Advantage in Retail Settings (1st ed.). IGI Global. doi:10.4018/978-1-4666-8297-9

Picot-Coupey, K., Huré, E., \& Piveteau, L. (2016). Channel design to enrich customers' shopping experiences: Synchronizing clicks with bricks in an omni-channel perspective - the Direct Optic case. International Journal of Retail \& Distribution Management, 44(3), 12. doi:10.1108/IJRDM-04-2015-0056

Piotrowicz, W., \& Cuthbertson, R. (2014). Introduction to the special issue: Information technology in retail: Toward omnichannel retailing. International Journal of Electronic Commerce, 18(4), 5-16. doi:10.2753/ JEC1086-4415180400

Piotrowicz, W., \& Cuthbertson, R. (2019a). Exploring omnichannel retailing: common expectations and diverse reality. In W. Piotrowicz \& R. Cuthbertson (Eds.), Exploring Omnichannel Retailing: Common Expectations and Diverse Realities (pp. 1-10). Springer. doi:10.1007/978-3-319-98273-1_1

Piotrowicz, W., \& Cuthbertson, R. (2019b). Last mile framework for omnichannel retailing: delivery from the customer perspective. In W. Piotrowicz \& R. Cuthbertson (Eds.), Exploring Omnichannel Retailing: Common Expectations and Diverse Realities (pp. 267-288). Springer. doi:10.1007/978-3-319-98273-1_12

Radhi, M., \& Zhang, G. (2018). Pricing policies for a dual-channel retailer with cross-channel returns. Computers \& Industrial Engineering, 119, 63-75. doi:10.1016/j.cie.2018.03.020

Rangaswamy, A., \& Van Bruggen, G. H. (2005). Opportunities and challenges in multichannel marketing: An introduction to the special issue. Journal of Interactive Marketing, 19(2), 5-11. doi:10.1002/dir.20037

Research and Markets. (2021, April). Retail Omni-Channel Commerce Platform - Global Market Trajectory \& Analytics (No. 4845822). https://www.researchandmarkets.com/reports/4845822/retail-omni-channel-commerceplatform-global?

360 . Research Reports. (2021, March 26). Global Retail Omni-Channel Commerce Platform Market 20212027 Research Report Analysis By Growing Demands, Current \& Future Trends, Impact of COVID-19, Investment Opportunity and Market Size Estimation. MarketWatch. https://www.marketwatch.com/press-release/globalretail-omni-channel-commerce-platform-market-2021-2027-research-report-analysis-by-growing-demandscurrent-future-trends-impact-of-covid-19-investment-opportunity-and-market-size-estimation-2021-03-25?

Ridder, H.-G. (2017). The theory contribution of case study research designs. Business Research, 10(2), 281-305. doi:10.1007/s40685-017-0045-z

Rigby, D. (2011). The future of shopping. Harvard Business Review, 89(12), 65-76.

Rodríguez-Torrico, P., San José Cabezudo, R., \& San-Martín, S. (2017). Tell me what they are like and I will tell you where they buy. An analysis of omnichannel consumer behavior. Computers in Human Behavior, 68 , 465-471. doi:10.1016/j.chb.2016.11.064

Ross, J. W., Beath, C. M., \& Sebastian, I. M. (2017). How to develop a great digital strategy. MIT Sloan Management Review, 58(2), 7-9.

Rusanen, O. (2018). Crafting an omnichannel strategy: Identifying sources of competitive advantage and implementation barriers. In W. Piotrowicz \& W. Cuthbertson (Eds.), Exploring the reality of omnichannel retailing: Common Expectations and Diverse Realities (pp. 11-40). Springer.

Saghiri, S., Wilding, R., Mena, C., \& Bourlakis, M. (2017). Toward a three-dimensional framework for omnichannel. Journal of Business Research, 77, 53-67. doi:10.1016/j.jbusres.2017.03.025

Sampson, R. C. (2007). R\&D Alliances and Firm Performance: The Impact of Technological Diversity and Alliance Organization on Innovation. Academy of Management Journal, 50(2), 364-386. doi:10.5465/ amj.2007.24634443 
Satta, G., Parola, F., Penco, L., \& Esposito de Falco, S. (2015). Insights to technological alliances and financial resources as antecedents of high-tech firms' innovative performance. $R \&$ D Management, 46(S1), $127-144$. doi:10.1111/radm.12117

Schoenecker, T., \& Cooper, A. (1998). The Role of Firm Resources and Organizational Attributes in Determining Entry Timing: A Cross-Industry Study. Strategic Management Journal, 19(12), 1127-1143. doi:10.1002/ (SICI)1097-0266(1998120)19:12<1127::AID-SMJ7>3.0.CO;2-4

Shen, X.-L., Li, Y.-J., Sun, Y., \& Wang, N. (2018). Channel integration quality, perceived fluency and omnichannel service usage: The moderating roles of internal and external usage experience. Decision Support Systems, 109, 61-73. doi:10.1016/j.dss.2018.01.006

Shi, S., Wang, Y., Chen, X., \& Zhang, Q. (2020). Conceptualization of omnichannel customer experience and its impact on shopping intention: A mixed-method approach. International Journal of Information Management, 50, 325-336. doi:10.1016/j.ijinfomgt.2019.09.001

Sood, A., \& Tellis, G. J. (2010). Demystifying Disruption: A New Model for Understanding and Predicting Disruptive Technologies. SSRN Electronic Journal, 4-52. 10.2139/ssrn.1629493

Sorescu, A., Frambach, R. T., Singh, J., Rangaswamy, A., \& Bridges, C. (2011). Innovations in retail business models. Journal of Retailing, 87, S3-S16. doi:10.1016/j.jretai.2011.04.005

Subramaniam, M., Iyer, B., \& Venkatraman, V. (2019). Competing in digital ecosystems. Business Horizons, 62(1), 83-94. doi:10.1016/j.bushor.2018.08.013

Taufique Hossain, T. M., Akter, S., Kattiyapornpong, U., \& Wamba, S. F. (2017). The Impact of Integration Quality on Customer Equity in Data Driven Omnichannel Services Marketing. Procedia Computer Science, 121, 784-790. doi:10.1016/j.procs.2017.11.101

Taylor, D., Brockhaus, S., Knemeyer, A., \& Murphy, P. (2019). Omnichannel fulfillment strategies: Defining the concept and building an agenda for future inquiry. International Journal of Logistics Management, 30(3), 863-891. doi:10.1108/IJLM-09-2018-0223

Teece, D. J. (1996). Firm organization, industrial structure, and technological innovation. Journal of Economic Behavior \& Organization, 31(2), 193-224.

Teece, D. J. (2010). Business Models, Business Strategy and Innovation. Long Range Planning, 43(2-3), $172-194$.

Verhoef, P. C., Kannan, P., \& Inman, J. J. (2015). From Multi-Channel Retailing to Omni-Channel Retailing. Journal of Retailing, 91(2), 174-181.

Visnjic, I., Neely, A., \& Jovanovic, M. (2018). The Path to Outcome Delivery: Interplay of Service Market Strategy and Open Business Models. Technovation, 72-73(April-May), 46-59.

Wang, J., Zheng, B., \& Liu, H. (2020). Satisfying consumers all around: A multidisciplinary view of omnichannel retail. Industrial Management \& Data Systems, 121(1), 158-171.

Wiener, M., Hoßbach, N., \& Saunders, C. (2018). Omnichannel businesses in the publishing and retailing industries: Synergies and tensions between coexisting online and offline business models. Decision Support Systems, 109, 15-26.

Wirtz, J., Patterson, P. G., Kunz, W. H., Gruber, T., Lu, V. N., Paluch, S., \& Martins, A. (2018). Brave new world: Service robots in the frontline. Journal of Service Management, 29(5), 907-931.

Zhang, J., Farris, P., Irvin, J.W., Kushwaha, T., Steenburgh, T. J., \& Weitz, B. A. (2009). Crafting Integrated Multichannel Retailing Strategies. SSRN Electronic Journal, 15.

Zhang, J., Farris, P. W., Irvin, J. W., Kushwaha, T., Steenburgh, T. J., \& Weitz, B. A. (2010). Crafting Integrated Multichannel Retailing Strategies. Journal of Interactive Marketing, 24(2), 168-180.

Zhang, J., Xu, Q., \& He, Y. (2018). Omnichannel retail operations with consumer returns and order cancellation. Transportation Research Part E, Logistics and Transportation Review, 118, 308-324.

Zisko, A. (2019, May 22). Ikea's Omnichannel Experiment. Home Furnishings News. https://www.hfndigital. com/news/ikeas-omnichannel-experiment/ 
International Journal of E-Business Research

Volume $18 \cdot$ Issue 2

Saiyed Wajid Ali is Associate Professor in the Centre for Management Studies at Jamia Millia Islamia University, New Delhi, India.

Tahir Ahmad Wani is Assistant Professor in the Department of Humanities, Social Sciences and Management at National Institute of Technology Srinagar, Jammu and Kashmir, India.

Nikita Tyagi is a research scholar at Centre for Management Studies, Jamia Millia Islamia University, New Delhi, India. 